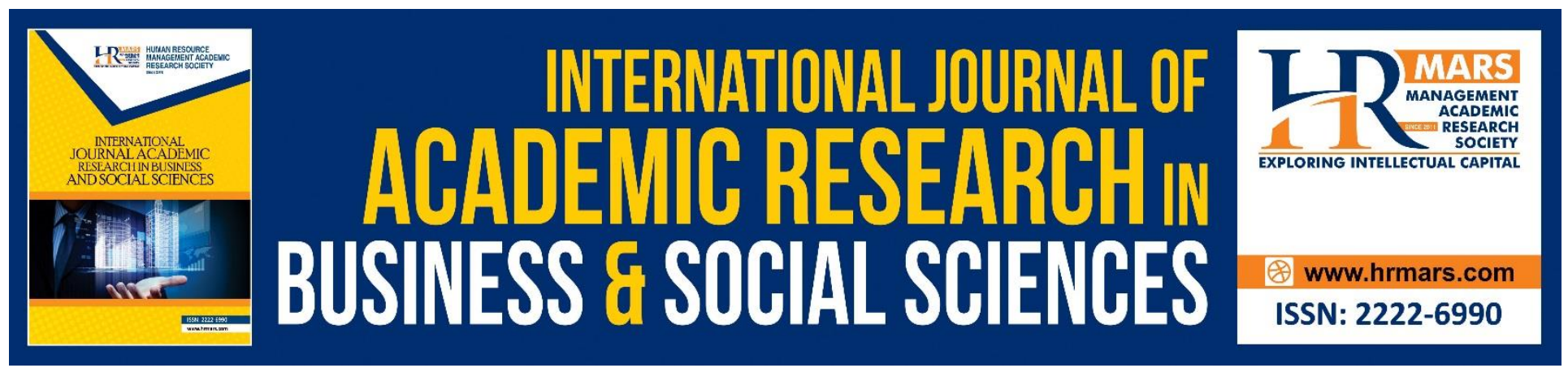

\title{
Organizational Citizenship Behavior in Malaysian Higher Educational Institutions
}

Rosafizah Mohamed Idrus, Khairuddin Idris, Zoharah Omar, Mohd Ashraff Mohd Anuar, Hasfizani Ariffin

To Link this Article: http://dx.doi.org/10.6007/IJARBSS/v9-i6/5965

DOI: $10.6007 /$ IJARBSS/v9-i6/5965

Received: 15 April 2019, Revised: 20 May 2019, Accepted: 06 June 2019

Published Online: 29 June 2019

In-Text Citation: (Idrus, Idris, Omar, Anuar, \& Ariffin, 2019)

To Cite this Article: Idrus, R. M., Idris, K., Omar, Z., Anuar, M. A. M., \& Ariffin, H. (2019). Organizational

Citizenship Behavior in Malaysian Higher Educational Institutions. International Journal of Academic

Research in Business and Social Sciences, 9(6), 462-477.

Copyright: (c) 2019 The Author(s)

Published by Human Resource Management Academic Research Society (www.hrmars.com)

This article is published under the Creative Commons Attribution (CC BY 4.0) license. Anyone may reproduce, distribute, translate and create derivative works of this article (for both commercial and non-commercial purposes), subject to full attribution to the original publication and authors. The full terms of this license may be seen

at: http://creativecommons.org/licences/by/4.0/legalcode

Vol. 9, No. 6, 2019, Pg. 462 - 477

http://hrmars.com/index.php/pages/detail/IJARBSS

JOURNAL HOMEPAGE

Full Terms \& Conditions of access and use can be found at http://hrmars.com/index.php/pages/detail/publication-ethics 


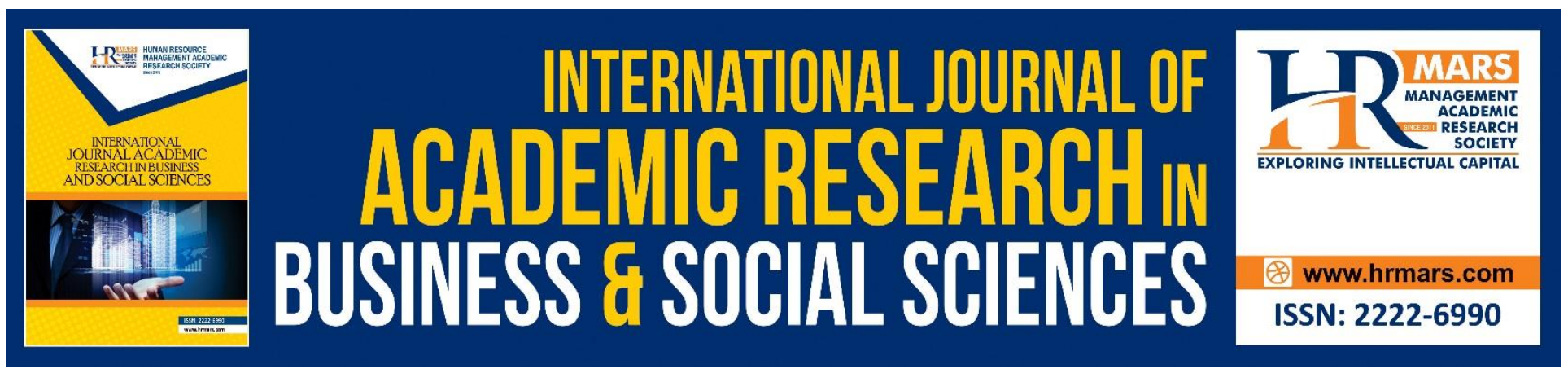

\title{
Organizational Citizenship Behavior in Malaysian Higher Educational Institutions
}

\section{Rosafizah, MOHAMED IDRUS ${ }^{a}$, Khairuddin, IDRIS, ${ }^{\mathrm{b}}$ Zoharah, Omar ${ }^{\mathrm{c}}$, Mohd Ashraff, MOHD ANUAR, ${ }^{\mathrm{d}}$ Hasfizani, ARIFFIN ${ }^{\mathrm{e}}$}

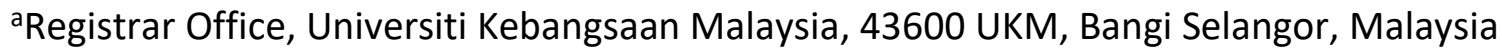 \\ $b, c, d$ Department of Professional Development and Continuing Education, Faculty of Education \\ 43400 UPM Serdang, Selangor, Malaysia \\ 'Registrar Office, Universiti Sains Malaysia, 11800 USM Pulau Pinang, Malaysia \\ Email: *rmi@ukm.edu.my
}

\begin{abstract}
Organizational citizenship behavior is a unique aspect of employee's behaviors in the workplace which is regarded as one of the important requirements and pre requisite for organizational effectiveness. Therefore, respective top management of the organizations are driven to revisit means and ways to improve, motivate and improvise strength of each employee. Thereby, employees with organizational positive attitudes which encompasses citizenship behavior will propel the organizations in achieving effective organizational implications and outcomes in this new global economy of the twenty first century. In every organization especially in the Higher Education Institutions it is significantly imperative to examine and analyse the contribution of citizenship behavior in Malaysia context of this industry as it seen very scarce. For this reason, this study will be focusing on the level of the Citizenship Behavior, in the context of Malaysian Higher Educational Institutions which with the objective to address on the reason as to why RU staffs willing to put extra effort in undertaking their tasks beyond their job description. Data gathered from 487 staffs in five Higher Educational Institutions in Malaysia and results shown that, staffs that undertake their responsibility at the workplace above and beyond their official responsibility is normally vested with higher level in Citizenship Behavior. Suggestions from the finding and future research on this citizenship behavior were also discussed whereby it is hoped that this study can contribute towards better understanding of the concept of Organization Citizenship Behavior especially in the context of Malaysian Higher Educational Institutions.
\end{abstract}

Keywords: Malaysian Higher Educational Institutions, Organizational Citizenship Behavior, Organizational Effectiveness, Positive Organizational Behavior 


\section{Introduction}

An effective employee who is able to function from within with insignificant problems is seen as an important aspect of an effective organization. Some of these internal functions frequently embraces the strong work culture, positive working environment, good communication and positive work behavior (Hussin \& Chin, 2017; Mohammadi et al., 2016). The positive work behavior in the practice of positive organizational behavior should be observed at each level of management which is from the top management to the most bottom level in ensuring employee effectiveness. This positive organizational behavior focuses and encourages leaders to center on employees' strength and fixing weaknesses. Quick et al., (2010) refers to positive organizational behavior as the development of positively-oriented human resource strengths factors within individuals that can be measured, developed, and effectively managed for performance improvement in today's workplace. It is an important factors in the workplace whereby success necessitates higher and higher performance (Quick et al., 2010). Therefore, it is clear that positive organizational behavior organization is the catalyst for effective employees in the workplace as by having these traits subtly it acts as motivator and module the behavior of employees at the respective organization (Quick et al., 2010).

The main component in ensuring the elevation of effectiveness of an organization is the employees. Each and every one of the employees that put in greater commitment and dedication without being forced or asked to do in undertaking their tasks at the workplace which is actually known as positive organizational behavior will benefit not only to oneself but most importantly will propel the higher effectiveness and success of the organization itself. This extra-role behavior is called as Organizational Citizenship Behavior (hereafter called OCB). OCB is fast becoming a unique aspect of employee's behaviors in the workplace. A key aspect of OCB is the voluntary behavior in undertaking tasks given or voluntarily done which is not part of the employee's job description and the outcome will extend the benefits to others and will profit the organization in the long run (Adewale et al., 2017; Gupta et al., 2017; Organ et al., 2006; Podsakoff et al., 2000). This voluntary behavior is closely related to individual employee strengths that form their behaviors and attitudes in the workplace. Therefore, it is vitally important to determine the level of OCB that will enhance the occurrence of OCB as a positive orientation of the strengths in human psychological capacities of respective employees.

\section{Organizational Citizenship Behavior}

An extensive study of OCB which placed the focus of research on positive oriented human resource, and this extensive study area had been going on for the past two decades. The term citizenship behavior is rooted in behavioral science study whereby this concept was articulated by Barnard in 1938 as cooperative behavior and Katz in 1964 as extra role behaviors. Since then OCB is also known as "the good soldier syndrome", Contextual Performance, Organizational Spontaneity, Civic Organizational Behavior and Prosocial Organizational Behavior (Borman \& Motowidlo, 1997; Brief \& Motowidlo, 1986; George \& Brief, 1992; George \& Jones, 1997; Kabasakal et al., 2011; Organ et al, 2006; Podsakoff et al., 2000). Whilst these terms are used synonymously with OCB yet these range of terminologies vary from one another in certain aspect. For instance, some term includes behavior which is officially rewarded by organization such as contextual performance and organizational 
INTERNATIONAL JOURNAL OF ACADEMIC RESEARCH IN BUSINESS AND SOCIAL SCIENCES Vol. 9, No. 6, June, 2019, E-ISSN: 2222-6990 @ 2019 HRMARS

spontaneity behavior (Borman \& Motowidlo, 1997; George \& Brief, 1992). Whereas, OCB is not recognized by means of formal reward as the behavior is executed by the employee as own choice (Organ et al, 2006; Podsakoff et. al. 2000). Regardless of that, it is found one thing in common which are the emphasize put in the area or spot of the behavior which encompasses on the cooperation and facilitating other employee at the workplace and sometimes merely displaying the behavior of the employee that will go to extra mile voluntarily undertaking tasks that goes beyond the limits of required formal job descriptions and role expectations (Kabasakal et al., 2011; Organ, 1997; Organ et al., 2006; Podsakoff et al., 2000).

OCB is consistently used in literatures compared to other terminologies as OCB frequently promotes the effective functions of the organization based on four main aspects. Firstly, OCB is informal behaviors or gestures which extend the benefits to both, individual and organization (Khan \& Rashid, 2012; Organ, 1997; Paul et al., 2016). Secondly, OCB is a constructive and voluntary behaviors undertaken by the respective employee in carrying out their duties which is not stated in their job description (Adewale et al., 2017; Aslan et al., 2013; Organ et al., 2006; Sabahi \& Dashti, 2016). And most importantly it is a voluntary act. Thirdly, OCB is not only rewarded directly but it is also not acknowledged by the official reward and award system (Gupta et al., 2017; Podsakoff, et al., 2000). Finally, OCB is the behavior that benefits at both level, individual and organization which will have the end result in the effectiveness of the individual and covers the overall organizational effectiveness (Romlee et al., 2016; Vivek, 2016).

Most researcher defined OCB as discretionary behavior engaged by the individuals and organization too, goes beyond existing role expectations and it is done for the benefit of the organization (Abdulrab et al., 2018; Deng \& Guan, 2017; Organ 1997; Zhang et al., 2017). These behaviors are perceived as voluntary behaviors as the extra efforts in undertaking tasks beyond required contribution as stated in the official job description of an employee (Adewale et al., 2017; Aslan et al., 2013; Organ et al., 2006; Sabahi \& Dashti, 2016). On top of it, these contributions and efforts are not explicitly recognized in the formal reward system of the respective organization. It is the preparedness of the respective employees that put in work and energy willingly beyond the expected or anticipated job scope and effort and it is done without any expectation to be compensated or rewarded and this citizenship behavior improves effectiveness of the said individual as well as the performance of the organization (Paul et al., 2016; Romlee et al., 2016; Vivek, 2016).

OCB is referred to organizationally beneficial behaviors and gestures as a voluntary conduct and action extended by the employee on their own choice which is not required in the job description thereby, employees choose OCB as activities that contribute to organization effectiveness through numerous ways where OCB (i) improves employees and managerial output (Awang \& Ahmad, 2015; Organ 1997, Podsakoff et al., 2000); (ii) assists in coordinating activities within and across work groups (Gupta et al. 2017; Deng \& Guan 2017; Mahembe \& Engelbrecht, 2014); (iii) maximize organization's ability to attract and retain talent (Kabasakal et al., 2011; Podsakoff et al., 2000; Vivek, 2016); (iv) 
INTERNATIONAL JOURNAL OF ACADEMIC RESEARCH IN BUSINESS AND SOCIAL SCIENCES

Vol. 9, No. 6, June, 2019, E-ISSN: 2222-6990 @ 2019 HRMARS

enhances the stability of organization performance (Gupta et al. (2017); (v) enable organization to cope and compete in aggressive environment (Podsakoff et al, 2000).

\section{Higher Education Institutions}

The term higher education institution (hereafter called $\mathrm{HEI}$ ) is defined as the education beyond secondary with the purpose to increase values of an individual for a betterment of the society (Sunder, 2016). Sunder (2016) indicates that, it is part of vast responsibility of the HEls in preparing an individual(s) to be a holistic future leader which will bring improvement to the society. He further theorised that an education business is significant in developing human capital and also by increasing employability of an individual for the benefit of nation's economy (Sunder, 2016). He further posited that the basic mission of HEl will continue to be committed to the four principal goals as suggested by the World Conference on Higher Education in 1998 which include: 1) the development of new knowledge - the research function, 2) the training of highly qualified personnel - the teaching function, 3 ) the provision of services to society - the ethical function and 4) which implies social criticism (Sunder, 2016).

Higher education also plays a very important part in ensuring good social mobility, economic growth of the country as in the current situation of the twenty first century where globalization is relevant thereby, it placed HEls as one of the important platform in connecting knowledge, skills and expertise for the new global economy (Azman et al., 2000; Selvaratnam, 2016). Higher education is being tested through new opportunities, new situations, new markets and new technologies economy (Azman et al., 2000; Beerkens, 2010; Pucciarelli \& Kaplan, 2016; Selvaratnam, 2016) whereby that change the role of the higher education system into a player in providing high-level knowledge and skills in producing skilled manpower for educated workforce to meet the competitive global market (Selvaratnam, 2016).

The roles of the higher education have expanded massively lately and requiring reformation in education structure and content and then introduced in postgraduate education, training programs in upgrading and in the retooling of skills and knowledge, life-long learning education and multi-skills training (Beerkens, 2010; Pucciarelli \& Kaplan, 2016). It is predicted that Higher Education will participate immeasurably in economic development through research and innovation which then will strengthen the higher education institution from the traditional role into advancing social and cultural evolution of the society (Azman et al., 2000; Beerkens, 2010; Pucciarelli \& Kaplan, 2016; Selvaratnam, 2016).

\section{OCB in Higher Education Context}

Findings found in the empirical research has made known that OCB influenced workforce's attitudes and behavior and in $\mathrm{HEI}$ too, whereby the role of the $\mathrm{HEI}$ has become more important not only as providing high-level knowledge and skills but most importantly became crucial in producing skilled manpower that is needed to produce the educated workforce (Aslan et al., 2013; Gupta et al., 2017; Paul et al., 2016; Zhang et al., 2017). For this reason, the willingness of HEI employees to go above 
and beyond the call of duty in accomplishing their university's vision, goals and objectives will definitely contribute to the overall HEI effectiveness.

OCB that focuses on positive oriented human resource strengths is more effective in shaping employees' behaviors and attitudes in the workplace (Ahmad et al., 2017). OCB will brand these employees as voluntarily undertaking their tasks over and above their official job description and with the outcome benefitting themselves and the organization that they are working in. As OCB is fast becoming a unique aspect of employees, behaviors and attitudes in the workplace, there then need to study on how employees in HEls develops positive behavior by creating a positive work atmosphere and make the job valuable for themselves and others.

There is analysis revealed in literatures by previous researchers that identified two main issues regarding $O C B$ in the $\mathrm{HEI}$. Firstly, in understanding the antecedents of OCB such as commitment, creativity, emotional intelligence and resilience (Deng \& Guan, 2017; Khan \& Rashid, 2012; Paul et al., 2016; Sabahi \& Dashti, 2016). Secondly, in considering the positive consequences of OCB to the $\mathrm{HEl}$ such as increase in job satisfaction and motivation whereby, management of HEls requires engagements more frequent with the employee so that it will strongly align with its value, mission, vision, and goals (Aslan et al., 2013).

An engaged employee will utilize his or her emotion and behavior in unification with the HEI's value, mission, vision, and goals as they regard work has meaning and purpose, thereby they will show more OCB and these employees are resilience and prepared to do more than their usual job duties, which in turn, provide performance that is beyond expectations. Hence, top management in the HEls need to appreciate the behavior and attitude of its employees as these employees whom are resilience and emotionally stable will lead towards positive behavioral response. This will later unswerving lead to higher obligation to the $\mathrm{HEI}$ as well as positive working and learning environment that will increase OCB and HEI effectiveness (Mahembe \& Engelbrecht 2014; Vivek, 2016).

\section{Current Scenario on the Study of OCB in Malaysian HEI}

Currently the study of OCB in Malaysian HEl is still in the infancy stage. In the last ten years, the study of OCB in Malaysia were mostly positioned on the organizational justice, commitment, turnover intention, occupational stress, job satisfaction, leadership, culture, readiness to change and high performance organization. 
INTERNATIONAL JOURNAL OF ACADEMIC RESEARCH IN BUSINESS AND SOCIAL SCIENCES

Vol. 9, No. 6, June, 2019, E-ISSN: 2222-6990 @ 2019 HRMARS

Table 1.1: A reviewed on the OCB literature in Malaysian Higher Educational Context in the last ten years [2010 - 2019]

\begin{tabular}{lcl}
\hline \multicolumn{1}{c}{ Authors } & Antecedent of OCB & \multicolumn{1}{c}{ Finding } \\
\hline $\begin{array}{l}\text { 1. Abdulrab et al. (2018) } \\
\text { [Social Exchange } \\
\text { Theory] }\end{array}$ & $\begin{array}{c}\text { Psychological } \\
\text { Empowerment, } \\
\text { Organizational Support }\end{array}$ & $\begin{array}{l}\text { Perceived organizational support is related to } \\
\text { psychological empowerment in improving employees } \\
\text { work attitude and commitment to the university. }\end{array}$ \\
$\begin{array}{l}\text { 2. Aslan et al. (2013) } \\
\text { Organization Support }\end{array}$ & $\begin{array}{l}\text { Study done on academician in Malaysian Public } \\
\text { Universities on antecedents and consequences of job } \\
\text { satisfaction, organizational support on OCB. }\end{array}$ \\
$\begin{array}{l}\text { 3. Awang et al. (2015) } \\
\text { [Social Exchange } \\
\text { Theory] }\end{array}$ & Organizational Justice & $\begin{array}{l}\text { Significant relationship of distributive justice and } \\
\text { interactional justice on OCB among academician in } \\
\text { Malaysian Polytechnics. }\end{array}$
\end{tabular}

4. Hussin \& Chin (2017) Athenian Model of OCB

Loyalty, commitment, and patriotism will increase [Social Exchange organizational citizens who have professional, ethical, Theory] and moral conscience to support their university's growth, development, and sustainability.

5. Khan \& Rashid (2012)

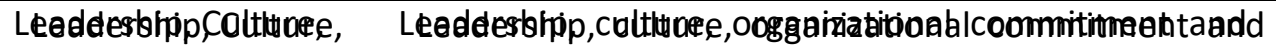

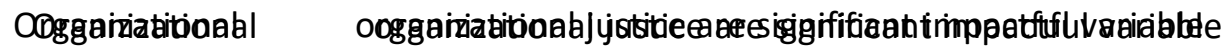

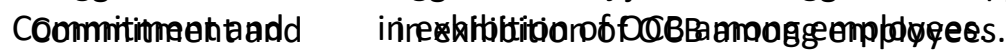

Juatitice

\begin{tabular}{llll}
\hline \multicolumn{1}{c}{ Authors } & Antecedent of OCB & \multicolumn{1}{c}{ Finding } \\
\hline 6. & Krishnan et al. & Job Satisfaction, & Significant relationship between job characteristics, job \\
& (2010) & Motivational Job & satisfaction and OCB. \\
& Characteristics &
\end{tabular}

7. Mohammad et al. Job Satisfaction (2011) [Social Intrinsic and extrinsic job satisfaction will encourage staffs to cultivating OCB.

Exchange Theory]

8. Mohammadi et al. Quality Work Life (2016) [Organ's OCB

Model]

OCB can be improved by quality of work life program which increase employees' satisfaction and commitment

9. Romlee et al (2018)

High Performance Organization
Sportsmanship and civic virtue will help organizations to improve efficiencies and increase the productivity via High Performance Organization.

From the above Table, it is said that there are limited number of researches undertaken until to date, emphasized on OCB in Malaysian HEl. There are in a few studies undertaken, whereby the 
respondents were mostly academician, support staff, managerial staffs and students. Nevertheless, it is found that respondents from the non-academic staff group such as managerial and support staffs are scarce. A study by Mohammadi et al., (2016) in a comparative study on quality of work life and OCB which was carried out among administrative staffs in private universities in Malaysia, with findings that OCB can be improved by quality of work life program which increase employees' satisfaction and commitment. In another study by Mohammad et al., (2011) among 79 library and the economic and business faculty employees in Universiti Kebangsaan Malaysia (UKM), found out that intrinsic and extrinsic job satisfaction are both important factors in cultivating citizenship behaviors that can benefit HEls. They further hypothesized that both intrinsic and extrinsic job satisfaction will encourage these staffs to be more willingly to exhibit voluntary behavior that is above and beyond of their job requirement that will benefit the university as a whole (Mohammad et al., 2011).

Similarly, Krishnan et al., (2010) studied the relationship between three motivational job characteristics namely job autonomy, job variety and job significance with job satisfaction and OCB among 125 employees in a public higher education in Malaysia. Their findings disclosed that there is significant positive relations between three job characteristics dimensions and job satisfaction, between job satisfaction and OCB, and between job characteristics and OCB besides a partial mediation of motivational job characteristics effects on OCB via job satisfaction. In addition, Romlee et al. (2016) studied on the two dimension of OCBO namely civic virtue and sportsmanship with high performance organization among 284 student in Universiti Utara Malaysia (UUM). Their findings were consistent with De Waal (2010) as well as William and Anderson (1991) which proven that there is significant relationship between sportsmanship and civic virtue with High Performance Organization whereby these two dimensions of OCBI will help organizations to improve efficiencies and increase the productivity.

Additionally, Hussin and Chin (2017) researched on OCB: its reconceptualization and tenability in university setting among 611 academicians in five premier universities in Malaysia. Hussin and Chin (2017) in their study incorporated the political conception of OCB in the Athenian model of citizenship, in which the core values are loyalty, commitment, and patriotism. Their finding revealed that academicians in public universities think of themselves as organizational citizens who have professional, ethical, and moral conscience to support their university's growth, development, and sustainability. Another study by Abdulrab et al., (2018) entitled the role of psychological empowerment as a mediating variable between perceived organizational support and OCB among academician in Malaysian HEls contributed to the body of knowledge on the role of perceived organizational support in increasing organizational citizenship behaviors among employees in public universities. Their study provide the management with clear reasons to pay more attention to perceived organizational support as an antecedent to psychological empowerment by caring about employees' opinions and well-being, valuing their contributions, providing assistance to them when needed, and by giving more focus on ways to demonstrate their support for individual employees, as this should improve their work attitude as well as commitment to the university. 
INTERNATIONAL JOURNAL OF ACADEMIC RESEARCH IN BUSINESS AND SOCIAL SCIENCES

Vol. 9, No. 6, June, 2019, E-ISSN: 2222-6990 @ 2019 HRMARS

\section{Methodology}

This study utilized a quantitative research method with self-administered survey questionnaires in the form of cross-sectional study. The sample of this study consists of 487 staffs from five premier universities in Malaysia. The OCB questionnaires was adapted from Fox et al., (2012), which consists of 20 items, in which first ten items were employed to measure OCB at individual level (OCBI) and next ten items were utilized to measure OCB in organization level (OCBO). All items are measured by a seven-point scale. This OCB checklist scale was reported as having high reliability ranging from 0.79 to 0.91 for $\mathrm{OCBI}$ and 0.87 to 0.94 for OCBO. Descriptive analysis for the entire sample were then performed by using SPSS version 25 to screen the collected data, analyze the reliability and validity of the data prior as well as to report on the level of OCBI and OCBO among staffs in Malaysian $\mathrm{HEI}$.

\section{Results and Discussion}

Demographic profile of respondent showed that two-third, 64.5\% (314) of the respondents are female with majority of the respondent are married (76.8\%). Almost all respondents are Malays $(96.5 \%)$ with age ranges from 31 to 40 years (45.6\%) and 30 years and below which constitute $23.8 \%$. Whereby, in this study, the participants working experience varied from 2 to more than 30 years of experience with the mean of 1.85 years and a standard deviation of .720 . Almost half $46 \%$ or 224 of the respondents have worked between 10 to 20 years. While the remaining of 34.5\% (168 respondents) have worked between 2 to 10 years and 19.5\% (95 respondents) have worked more than 20 years. In terms of academic qualification, almost half of the respondents (45\%) had an upper school degree (SPM/SPMV/GCE) while $42.9 \%$ had a Diploma/STPM/HSC.

The OCBI scale is made of 10 items. Upon CFA model, only 8 confirmed items left for further analysis. For OCBI, the mean summated OCBO scores are computed as a mean score ranged from I to 7 . The computed means scores compared using three levels, namely low (1.00 - 3.00), moderate (3.01 $5.00)$ and high (5.01-7.00). A total of 281 (57.7\%) respondent reported high in OCBI, followed by $202(41.5 \%)$ respondents reported moderate level of OCBI and only 4 (8\%) respondent reported low level of OCBI. It is also found out that the overall mean score of OCBI behavior is average (2.568) with standard deviation of .512 and variance of .262 which indicate that the respondents had a fairly high OCBI.

Whereas, the OCBO scale is made of 10 items. Upon CFA model all items are retained for further analysis. For OCBO, the mean summated OCBO scores are computed as a mean score ranged from I to 7. The computed means scores compared using three levels, namely low $(1.00-3.00)$, moderate $(3.01-5.00)$ and high $(5.01-7.00)$. The results showed that majority of respondents reported high in OCBO $(458,94 \%)$, followed by $29(6 \%)$ respondents reported moderate level of OCBO. It is also found out that the overall mean score of OCBO behavior is average (2.94) with standard deviation of .237 and variance of .056 which indicate that the respondents had a very high OCBO. The level of $\mathrm{OCBI}$ and $\mathrm{OCBO}$ of the respondents is presented in table 1.2 
INTERNATIONAL JOURNAL OF ACADEMIC RESEARCH IN BUSINESS AND SOCIAL SCIENCES

Vol. 9, No. 6, June, 2019, E-ISSN: 2222-6990 @ 2019 HRMARS

Table 1.2: Level of OCBI and OCBO $(n=487)$

\begin{tabular}{|c|c|c|c|c|c|}
\hline VARIABLE & FREQ & PERCENT & MEAN & SD & VARIANCE \\
\hline $\begin{aligned} \text { OCBI } & \\
\bullet & \text { Low }(1.00-3.00) \\
\text { - } & \text { Moderate }(3.01-5.00) \\
\text { - } & \text { High }(5.01-7.00)\end{aligned}$ & $\begin{array}{c}4 \\
202 \\
281\end{array}$ & $\begin{array}{c}8 \\
41.5 \\
57.7\end{array}$ & 2.568 & .512 & .262 \\
\hline VARIABLE & FREQ & PERCENT & MEAN & SD & VARIANCE \\
\hline $\begin{aligned} \text { OCBO } & \\
& - \\
\text { - } & \text { Low }(1.00-3.00) \\
\text { - } & \text { Hoderate }(3.01-5.00) \\
& \text { High }(5.01-7.00)\end{aligned}$ & $\begin{array}{c}- \\
29 \\
458\end{array}$ & $\begin{array}{c}- \\
6 \\
94\end{array}$ & 2.94 & .237 & .056 \\
\hline
\end{tabular}

The descriptive analysis for OCBI revealed that out of 487 respondents, 281 (57.7\%) are high in OCB and $202(41,5 \%)$ reported moderate in OCBI which showed that the staffs in the Malaysia HEl exhibit moderate to high level of OCB at work. This means that these staff are always willing to help colleagues with work related problem and voluntarily seeks to increase the welfare of others with expects no reward in return. This voluntary behavior is consistent with empirical finding by Syamsuddin et al., (2017) studied on factors that has direct effect on five dimension of OCB and the respondents are among 103 staffs of Institute Agama Islam Negeri Kendari, Indonesia. In their study, they established that IAIN Kendari staffs' OCB are indicators that they were able to motivate themselves to act voluntarily and had high desire to achieve success at workplace. However, in their study, Syamsuddin et al., (2017) did not separate the dimension of OCB into individual and organization.

Another study by Jeon and Koh (2014) in a comparative study on emotional intelligence, OCB, organizational commitment and organizational performance which was carried out in a hospital in Korea amongst the clinical nurses, with findings that OCB can be improved by influencing its nurse's attitude, behavior and commitment to the hospital. Additionally, Hussin and Chin (2017) researched on OCB: its reconceptualization and tenability in university setting among 611 academicians in five premier universities in Malaysia. Their finding suggested that high $O C B$ at individual level among academicians in public universities will propel them to think of themselves as organizational citizens who have professional, ethical, and moral conscience to support their university's growth, development, and sustainability. Amazingly, the descriptive analysis for OCBO showed that almost all respondent had high OCBO (94\%) and only $6 \%$ had moderate OCBO which indicate that support staffs 
INTERNATIONAL JOURNAL OF ACADEMIC RESEARCH IN BUSINESS AND SOCIAL SCIENCES

Vol. 9, No. 6, June, 2019, E-ISSN: 2222-6990 @ 2019 HRMARS

are willing to cooperate with the HEls by keeping up with development in the HEls, promote behavior that tent to stimulate cordial working relationship among staffs such as placing others at positions of high regard while dealing with them or giving advance notices.

Staffs' willingness to tolerate unpleasant and less ideal situations without grumbling, attend meetings and HEls functions that are not compulsory but are useful for HEls image. The results showed that supports staffs are much more willing to direct their OCB toward the organization rather at personal level. This suggest that staff feel a significant bond with their HEls and their coworkers. HEls in the vignette is very positive and seem to be a desired place of employment. The finding of this study is in line with Romlee et al., (2016) findings on the two dimensions of OCBO namely civic virtue and sportsmanship with high performance organization among 284 students in Universiti Utara Malaysia (UUM).

Their findings were consistent with Evans and Davis (2014) as well as William and Anderson (1991) which proven that there is significant relationship between sportsmanship and civic virtue with High Performance Organization whereby high level of these two dimensions of OCBO will help organizations to improve efficiencies and increase the productivity. Similarly, Krishnan et al (2010) studied the relationship between three motivational job characteristics namely job autonomy, job variety and job significance with job satisfaction and OCB among 125 employees in a public higher education in Malaysia. Their findings were in line with the present study whereby they disclosed that high level of OCBO significantly relates to job satisfaction whereby high level of OCBO will drive them to willingly get involve and engage in activities in the university which are beyond their official job descriptions.

\section{Implication}

In the literature, many researchers have recognized the importance of OCB in cultivating employees' strengths (Deng \& Guan, 2017). However, until to date, there are insufficient focus and not enough attention are given to both personal and work-related factors in cultivating employee's strength through OCB (Nafei, 2015). This is because, for the last two decades most researchers studied either on personal factors or work-related factors extensively as independent topic also they studied separately as background or history of OCB in different area of studies in organizational behavior (Nafei, 2015; Paul et al., 2016; Zhang et al., 2017). There are models of OCB studies, however, so far none of these model combines OCB with personal and work-related factors has been empirically tested in a single study. Therefore, there is a need to study both personal and work-related factors in cultivating employees' strength through OCB (Ahmad et al., 2017; Chun et al., 2013; Paul \& Garg, 2014; Sabahi \& Dashti, 2016).

In Malaysia, the study of OCB is still inadequate as most studies were focused on respondents from the pool of academician (Abdulrab et al., 2018; Aslan et al. 2013; Awang et al., 2015; Husin \& Chin, 2017), managerial staffs (Krishnan et al., 2010) or students (Romlee et al., 2018) but limited studies was done on support staff (Mohammadi et al., 2016). For this reason, there rise a need to explore 
antecedent of OCB as means and ways to improve, motivate and improvise the strength of support staffs of HEls whereby these employees with organizational positive attitudes which encompasses citizenship behavior that will steer the HEls to achieve organizational positive implications and outcomes in the new global economy of the twenty first century. These support staffs are the heart of HEls in which they are the pillar and play a vital role in a university. They are quite frequently left as the unsung heroes within the respective HEls as most research in the HEls context are center on academician, managerial staffs or students.

Besides, previous studies have established two major gaps in the literature on OCB. First, there is seemingly vague and unclear knowledge in the literature that focusing on both the personal and work-related factors with OCB (Nafei, 2015; Paul et al., 2016; Podsakoff et al., 2000). Second, very few studies have been done on different types of citizenship-like behaviors that related differently with certain individual-level or organizational-level factors the dependent variables (i.e. OCBI and OCBO) (Hussin \& Chin, 2017). Therefore, there is a need to examine personal and work-related factors as antecedent of OCB in the developing country such as Malaysia. There is also a necessity to find out which personal and work-related factors that would interact positively and significantly with different types of citizenship-like behaviors among employees in the Malaysian HEls.

Additionally, most studies use social exchange theory as the underlying theory in understanding the norm of reciprocity where mutual benefits received by employees will drive them to exchange with their willingness to voluntarily go beyond the call of their duty. Despite that, there is limited application of social cognitive theory in understanding employee's cognitions that can influence their voluntary behaviors. Since social cognitive theory imply that behavior is influenced by a combination of personal and environmental factors that interacts as a causal connection that affects each other bi-directionally, therefore, future research need to explore in a single study the relationship between both personal (cognitive and personal factor) and work-related factor (environment factor) in cultivating employee's strength through OCB (behavior). The use of social cognitive theory is imperative to analyze the fundamental association between behaviors, cognitive and personal factors as well as the environment act that affects each other bi-directionally and on how individual acquired and maintained certain behavior pattern through the three conducts in interaction will add to the body of knowledge in OCB and social cognitive theory literature.

The review of literature identified $O C B$ as an important variable in understanding behavior of employees. The study in this area of OCB is important to the management of Malaysian HEIs and the Malaysian government as it provides insight to the management of HEls in instructing and constructing the awareness on the magnitude of OCB in developing human resources. Specifically, it helps them to explore for ways to cultivate positive employees' strength that willed them, readily to go extra mile beyond their job responsibilities, therefore, the management of Malaysian HEls need to seek means and techniques on how to motivate and influence their employees to engage in citizenship behaviors. 
INTERNATIONAL JOURNAL OF ACADEMIC RESEARCH IN BUSINESS AND SOCIAL SCIENCES

Vol. 9, No. 6, June, 2019, E-ISSN: 2222-6990 @ 2019 HRMARS

\section{Suggestions for Future Research and Conclusion}

This study verified previous researcher findings that $O C B$ is beneficial to organization and the person performing the OCB as well. As the reason for indulging in OCB is very different as opposed to usual work behaviors, therefore, this study added to the body of knowledge in OCB literature by examining the significant of OCB in understanding on why some employees indulge in OCB, while others do not and most importantly to determine what are the factors that influence OCB in Malaysian HEls context. Additionally, from the literature, most studies used cross-sectional data which were collected from individual employees at the same point of time. Therefore, future research could employ longitudinal study which could provide better insight about the causality among study variables.

Past studies also revealed that there are limited number of research undertaken until to date which has been given, to both personal and work-related factors that can cultivate employee's strengths through OCB. As a result future studies need to provide empirically a new insight by examining in a single study on the contribution of personal and work-related factors on OCB especially in a nonwestern context such as Malaysia. This is because most studies pertaining OCB was done in western context which warrant this current study to rectify the need to examine the contribution of citizenship behavior in Malaysia context. .,As this current study has confirmed the importance of having a high level of OCBI and OCBO among staffs in the HEI whereby this citizenship behavior propel these staffs to willing put extra effort in undertaking their tasks beyond their job description that will in turn benefit the HEI in the long run. By establishing the importance of OCB level among staff in Malaysia HEI will propel top management in the HEI to design suitable interventions that aims at fostering $O C B$ that combine specific measure at the organization and individual level.

\section{References}

Abdulrab, M., Zumrah, A. R., Almaamari, Q., Al-Tahitah, A. N., Isaac, O., \& Ameenf, A. (2018). The Role of Psychological Empowerment as a Mediating Variable between Perceived Organizational Support and Organizational Citizenship Behaviour in Malaysian Higher Education Institutions. International Journal of Management and Human Science, 3(3), 1 -14.

Adewale, A. S., Ghavifekr, S., \& Daud, M. A. K. M. (2018). Leadership and Staff Organizational Citizenship Behaviour in Higher Education Institutions: A Quantitative Analysis. MOJEM: Malaysian Online Journal of Educational Management, 6(1), 36-52. hmad, S., Nisar, Q. A., Othman, N., \& Kamil, B. A. M. (2017). Do Emotional Intelligence \& Organizational Politics influence the Employee Work Behaviors and attitudes? Mediating Role of Political Skill. UKM Journal of Management, 51(3), 416- 432.

Aslan, A. S., Shaukata, M. Z., Ahmeda, I., Shaha, I. M., \& Mahfara, M. (2013). Job Satisfactions of Academics in Malaysian Public Universities. Procedia - Social and Behavioral Sciences, 114, 154 - 158.

Awang, R., \& Ahmad, W. M. R. W. (2015). The impact of organizational justice on organizational citizenship behavior in Malaysian higher education. Mediterranean Journal of Social Sciences, 6(5), 674. 
INTERNATIONAL JOURNAL OF ACADEMIC RESEARCH IN BUSINESS AND SOCIAL SCIENCES Vol. 9, No. 6, June, 2019, E-ISSN: 2222-6990 @ 2019 HRMARS

Azman, N., Sirat, M. \& Karim, M. A. (2010). Building future scenarios for Malaysian universities. Journal of Asian Public Policy, 3(1), 86 - 99. Barnard, C. I. (1938). The functions of the executive. Cambridge, MA: Harvard University Press.

Beerkens, E. (2010). Global models for the national research university: adoption and adaptation in Indonesia and Malaysia. Globalisation, Societies and Education, 8(3), 369-391.

Borman, W. C., \& Motowidlo, S. J. (1997). Task performance and contextual performance: The meaning for personnel selection research. Human Performance, 10, 99-109

Brief, A. P., \& Motowidlo, S. J. (1986). Prosocial organizational behaviors. Academy of Management Review, 11(4), 710-725.

De Waal, A. (2010). Achieving high performance in the public sector: What needs to be done?. Public Performance and Management Review, 34(1), 81-103.

Deng, X., \& Guan, Z. (2017). Creative leaders create 'unsung heroes': leader creativity and subordinate organizational citizenship behavior. Frontiers of Business Research in China, 11(1), 1-13.

Evans, W. R., \& Davis, W. (2014). Corporate citizenship and the employee: An organizational identification perspective. Human Performance, 27(2), 129-146. George, J. M., \& Brief, A. P. (1992). Feeling good-doing good: A conceptual analysis of the mood at work-organizational spontaneity relationship. Psychological Bulletin, 112, 310-329.

George, J. M., \& Jones, G. R. (1997). Organizational spontaneity in context. Human Performance, 10, 153-170.

Gupta, M., Shaheen, M., \& Reddy, P. K. (2017). Impact of psychological capital on organizational citizenship behavior: Mediation by work engagement. Journal of Management Development, 36 (7), 973-983.

Hussin, S., \& Chin, W. S. (2017). Organizational citizenship behavior: Its reconceptualization and tenability in university setting. MOJEM: Malaysian Online Journal of Educational Management, 2(4), 1-20. Jeon, K. D., \& Koh, M. S. (2014). Comparative study of emotional intelligence, organizational citizenship behavior, organizational commitment and organizational performance of clinical nurses in Korea. Journal of Korean Academy of Nursing Administration, 20(4), 446-454.

Kabasakal, H., Dastmalchian, A., \& Imer, P. (2011). Organizational citizenship behavior: A study of young executives in Canada, Iran, and Turkey. International Journal of Human Resource Management, 22(13), 2703-2729.

Katz, D. (1964). The Motivational Basis of Organizational Behavior. Behavior Science, 9 (2), 131 - 133.

Khan, S. K., \& Rashid, M. Z. A. (2012). The Mediating Effect of Organizational Commitment in the Organizational Culture, Leadership and Organizational Justice Relationship with Organizational Citizenship Behavior: A Study of Academicians in Private Higher Learning Institutions in Malaysia. International Journal of Business and Social Science, 3(8), $83-91$.

Krishnan, R., Omar, R., Ismail, I. R., Alias, M. A., Hamid, R. A., Ghani, M. A., \& Kanchymalay, K. (2010). Job satisfaction as a potential mediator between motivational job characteristics and organizational citizenship behavior: Evidence from Malaysia. Journal of Information Technology \& Economic Development, 1(1), 86 - 110 
INTERNATIONAL JOURNAL OF ACADEMIC RESEARCH IN BUSINESS AND SOCIAL SCIENCES Vol. 9, No. 6, June, 2019, E-ISSN: 2222-6990 @ 2019 HRMARS

Mahembe, B., \& Engelbrecht, A. S. (2014).The relationship between servant leadership, organisational citizenship behaviour and team effectiveness. SA Journal of Industrial Psychology, 40(1), 1 - 10.

Mohammad, J., Quoquab Habib, F., \& Zakaria, S. (2010). Organizational citizenship behavior and commitment: do age and tenure make any difference?. Business Management Quarterly Review, 1(3), 28-49.

Mohammadi, S., Kiumarsi, S., \& Hashemi, S. M. (2016). Quality of Work Life and Organizational Citizenship Behavior among the Employees in Private Universities in Malaysia. International Journal of Business and Innovation, 2(6), 48 - 58.

Nafei, W. (2015). Meta-analysis of the impact of psychological capital on quality of work life and organizational citizenship behavior: A study on Sadat City University. International Journal of Business Administration, 6(2), 42 - 59.

Organ, D. W. (1997). Organizational citizenship behavior: It's construct clean-up time. Human Performance, 10, 85-97.

Organ, D. W., Podsakoff, P. M., \& MacKenzie, S. B. (2006). Organizational citizenship behavior: Its nature, antecedents, and consequences. Beverly Hills, CA: Sage.

Podsakoff, P. M., MacKenzie, S. B., Paine, J. B., \& Bachrach, D. G. (2000). Organizational citizenship behaviors: A critical review of the theoretical and empirical literature and suggestions for future research. Journal of Management, 26(3), 513-563.

Paul, H., Bamel, U. K., \& Garg, P. (2016). Employee Resilience and OCB: Mediating Effects of Organizational Commitment. Vikalpa, 41(4), 308-324.

Paul, H., \& Garg, P. (2014). Organizational Commitment of Frontline Sales Professionals in India: Role of Resilience. International Journal of Business Insights \& Transformation,7(2). 12 - 18. Pucciarelli, F., \& Kaplan, A. (2016). Competition and strategy in higher education: Managing complexity and uncertainty. Business Horizons, 59 (3), 311-320

Quick, J. C., Cooper, C. L., Gibbs, P. C., Little, L. M., \& Nelson, D. L. (2010). Positive organizational behavior at work. International Review of Industrial and Organizational Psychology, 25. 253 291

Romlee, A. R., Talib, N. F. M., \& Shahuri, N. S. S. (2016). The relationship between organizational citizenship behavior and high performance organization from the perspective of the students in the higher education institution in Malaysia. Journal of Scientific Research and Development. 3 (5), 37-42.

Sabahi, A., \& Dashti, N. (2016). The effect of emotional intelligence and job satisfaction on organizational citizenship behavior. Management Science Letters, 6 (7), 475-480.

Selvaratnam, V. (2016). Malaysia's Higher Education and Quest for Developed Nation Status By 2020. Southeast Asian Affairs, 124 (4), 199 - 221.

Sirat, M. \& Azman, N. (2014). Malaysia's National Higher Education Research Institute (IPPTN): narrowing the research-policy gap in dynamic higher education system. Studies in Higher Education, 39 (8), 1451 - 1462. 
Sunder M, V. (2016). Constructs of quality in higher education services. International Journal of Productivity and Performance Management, 65(8), 1091-1111.

Syamsuddin, S., La Ringgasa, L. R, \& Badarwan, B. (2017). The Effect of Self-efficacy on Organizational Citizenship Behavior (OCB) Employees of Institut Agama Islam Negeri Kendari. Langkawi: Journal of The Association for Arabic and English, 3(1), 63-79.

Vivek, S. A. (2016). Impact of organizational citizenship behavior on managerial effectiveness. Prabandhan: Indian Journal of Management, 9 (2), 7-18.

Williams, L. J., \& Anderson, S. E. (1991). Job satisfaction and organizational commitment as predictors of organizational citizenship and in-role behaviors. Journal of Management, 17, 601-617

Zhang, L., Qiu, Y., \& Teng, E. (2017). Cross-level relationships between justice climate and organizational citizenship behavior: Organizational support as mediator. Social Behavior and Personality: An International Journal, 45 (3), 387-397. 